\title{
Com quantos gigabytes se faz uma família: a reconfiguração da teoria do fato jurídico, de Pontes de Miranda, no Direito das famílias a partir das relações virtuais
}

\author{
With how many gigabytes it makes a family: the \\ reconfiguration of the legal fact theory of Pontes \\ de Miranda in the Law of families from the virtual \\ relations
}

\author{
Wilson Engelmann* \\ Guilherme Wünsch ${ }^{* *}$
}

\section{Resumo}

Este artigo discute, a partir das perspectivas inauguradas pelo movimento de constitucionalização do Direito Privado, os seus reflexos na configuração do Direito de Família, notadamente por meio da family by design, configurando uma novidade para o Direito Civil brasileiro, especialmente com a introdução da coparentalidade ou doador conhecido. Para albergar juridicamente essas novidades desencadeadas pelas pessoas no seio dos modelos de convivência familiar, passa-se pela necessidade de ressignificar a estruturação do suporte fático, inserido no Direito Privado brasileiro por intermédio da teoria do fato jurídico, de Pontes de Miranda. Utilizando-se do método fenomenológicohermenêutico, os autores apresentam alternativas para a juridicização desse novo enlace de construção de relações de família. $O$ desafio é trazer

Doutor e Mestre em Direito Público pelo Programa de Pós-Graduação em Direito (Mestrado e Doutorado) da Universidade do Vale do Rio dos Sinos - Unisinos/RS/Brasil; Professor do mesmo Programa nas atividades: Transformações Jurídicas das Relações Privadas (Mestrado) e Os Desafios das Transformações Contemporâneas do Direito Privado (Doutorado); Coordenador Executivo do Mestrado Profissional em Direito da Empresa e dos Negócios da Unisinos; Líder do Grupo de Pesquisa JUSNANO (CNPq); Bolsista de Produtividade em Pesquisa do CNPq. E-mail: wengelmann@unisinos.br.

** Doutorando e Mestre em Direito Público pelo Programa de Pós-Graduação em Direito da Unisinos/RS; Professor do Curso de Graduação em Direito da Unisinos. E-mail: guilhermeipa@ yahoo.com.br. 
efetividade ao conteúdo inserido na Constituição do Brasil, como a dignidade da pessoa humana, que é colocada como o vetor chave para promover a aplicação do Código Civil à luz do arcabouço principiológico constitucional. As novas tecnologias permitem a instalação crescente da inovação na sociedade brasileira e internacional, gerando desafios ao Direito no sentido de dar respostas adequadas constitucionalmente e, ao mesmo tempo, em exigindo aberturas interdisciplinares, levando o Direito a complementar o processo de juridicização dos fatos sociais com as contribuições de outras áreas, como a Filosofia, a Sociologia e a Bioética.

Palavras-chave: Constituição. Direito privado. Família. Design. Suporte fático.

\section{Abstract}

This article discusses, from the perspectives opened by the movement of Private Law constitutionalising, your reflexes in the family law setting, notably through family by design, setting a novelty for the Brazilian civil law, especially with the introduction co-parenting or known donor. To legally accommodate these new developments triggered by people within the family environment models, it passes by the need to reframe the structuring of factual support, inserted into the Brazilian Private Law through the Legal Suit Theory of Pontes de Miranda. Using the phenomenological-hermeneutic method, the authors present alternatives to legalize this new link building family relationships. The challenge is to bring effectiveness to the content inserted in the Constitution of Brazil, for example, the dignity of the human person, which is placed as the key driver to promote the application of the Civil Code in the light of the constitutional principle framework. New technologies allow the growing installation of innovation in Brazilian and international society, generating challenges to the law, in order to give appropriate constitutionally answers and at the same time, they require interdisciplinary openings, bringing the law to complement the legalization process of social facts, with contributions from other areas such as Philosophy, Sociology and Bioethics.

Keywords: Constitution. Private law. Family. Design. Factual support.

\section{Introdução}

O artigo tem como tema o estudo acerca da necessidade de releitura de um dos pilares em que se estrutura o Direito Civil, qual seja: 
a família, desde a sua perspectiva clássica até a sua reinterpretação a partir dos fenômenos da constitucionalização e despatrimonialização do Direito Privado. Este artigo delimita-se especificamente a partir das novas configurações das famílias no ordenamento jurídico brasileiro, notadamente marcado pela repersonalização e pluralidade de relações, fazendo surgir diferentes desenhos e conformações nas relações interpessoais. Um dos recentes modelos familiares que será destacado no texto é o denominado family by design (família por design), oriunda da rede mundial de computadores, a partir da página eletrônica http:// www.familybydesign.com/, a qual apresenta como principal objetivo fomentar a chamada coparentalidade ou doador conhecido.

É nesse contexto que uma nova entidade familiar parece surgir, a da coparentalidade, formada pelo filho e os co-pais que, identificados, formam a família apenas destinada ao filho internético, que não conhecerá uma estruturação familiar tradicional, mas apenas um pai e uma mãe, que conceberam um filho com a assistência genética um do outro, nada mais havendo entre eles em termos de relação familiar.

Aqui, a figura da afetividade ganha relevo no artigo, pois eis que o contemporâneo Direito de família assumiu uma marca plural, de inclusão, em nome de um chamado princípio da afetividade, de sorte que os laços que formam a família hodierna são muito mais existenciais do que patrimoniais. No entanto, assume-se que é tarefa difícil refletir o paradigma da afetividade em uma estruturação relacional que contempla a escolha de perfis e o fim procriativo a partir de um acordo de coparentalidade firmado entre duas pessoas.

Com efeito, claro que se percebe que filhos cibernéticos concebidos por pais internéticos, embora algumas críticas bioéticas, constituem uma nova realidade que não pode ser desconsiderada pelo Direito de Família. Os fatos da vida conferem realidades diferentes, no sentido da comunidade familiar, em seus mais diversos segmentos, razão pela qual, repisa-se, o artigo discutirá a existência de um novo modelo familiar biotecnológico, formatado por uma necessária retomada do conceito de contrato a partir de seu viés existencial. 
Por tal razão, o problema de pesquisa do artigo intenta ao questionamento acerca da forma que se devem refletir os novos arranjos familiares e o efeito sobre o projeto parental quando esses desenhos não possuem uma previsão legislativa no ordenamento jurídico, embora se constituam em uma realidade fática. Como hipótese a ser comprovada, sustenta-se que a emergência de novos modelos de famílias, enquanto categorias jurídicas no Direito Contemporâneo, possibilitam o surgimento de inúmeros e diferentes arranjos, cujo exame implica o olhar conjunto dos pilares em que se assenta o Direito Civil. Mas não em seu sentido puramente dogmático, conquanto busca-se tal releitura nas bases da teoria do fato jurídico, de Pontes de Miranda, mormente na readaptação do conceito de suporte fático para um suporte constitucionalizado, apto a inserir, no contexto do paradigma da afetividade como valor jurídico, uma superação que contemple a perspectiva existencial e funcional dos pilares do Direito Civil, marcado, hodiernamente, pela sua repersonalização.

O tema do artigo demonstra-se de assaz relevância e justifica-se à medida que os avanços alcançados pelo desenvolvimento científico e tecnológico nas últimas décadas, especialmente nos campos da biologia e da saúde, colocam a humanidade diante de situações que pouco tempo atrás pareciam inimagináveis.

Os indivíduos estão convencidos de que se vive na idade da técnica, mas na facilidade com que se utilizam os instrumentos que encurtam o espaço e o tempo, amenizam a dor, tornam ineficazes as normas sobre as quais se assentam todas as morais. E assim corre-se o risco de não haver o questionamento sobre o modo de ser humano na idade da técnica, como se fosse uma obrigação estar participando dela.

Trata-se da necessidade do rompimento com aquele paradigma estanque, superando-se a chamada dicotomia entre o Direito Público e o Direito Privado. Ao se recepcionar na Constituição Federal temas que antes compreendiam apenas ao estatuto privado, provocam-se transformações no sistema do Direito Civil clássico, ou seja, a adaptação a uma nova realidade econômico-social, que obrigou o intérprete do Direito a repensar os valores ideologicamente consagrados no 
ordenamento jurídico e as influências interdisciplinares sofridas por ele nessa mutação.

O Direito Privado igualmente passa por um momento de transformação em que novos arranjos se constituem em um ambiente de pluralidade de formas familiares. Assim sendo, quer-se contribuir para o debate com um recorte epistemológico que contemple o diálogo proposto com os estudos acerca do desenvolvimento de novas tecnologias, que influenciam a formação de relacionamentos humanos e familiares, superando-se uma visão puramente dogmática do tema e pautandose o exame a partir de uma perspectiva interdisciplinar, focando nas orientações publicadas recentemente na Revista Nature (2015, p. 289):

A melhor ciência interdisciplinar vem da percepção de que há questões urgentes ou problemas que não podem ser adequadamente tratados por pesquisadores vinculados somente a uma área de conhecimento ou atividade de investigação. [...] Uma abordagem interdisciplinar deve conduzir as pessoas a fazer perguntas e resolver problemas que nunca foram lançadas anteriormente. (TOO CLOSE FOR COMFORT, 2015, p. 289).

A partir do alinhamento interdisciplinar para o desenvolvimento do texto, adota-se o método fenomenológico-hermenêutico. Sabendo-se que o método de abordagem visa aproximar os sujeitos (pesquisadores e autores deste artigo) e o objeto a ser pesquisado. Por isso, cabem algumas considerações sobre a metodologia que sustenta a construção deste artigo: o "método" fenomenológico-hermenêutico (STEIN, 1979). Já essa constatação fenomênica receberá a atribuição de sentido, a partir do círculo hermenêutico (GADAMER, 2002).

Concorda-se, portanto, com Lenio Luiz Streck (2004, p. 4) quando afirma: "o verdadeiro caráter do método fenomenológico não pode ser explicitado fora do movimento e da dinâmica da própria análise do objeto." [...] Em decorrência disso, "a introdução ao método fenomenológico somente é possível, portanto, na medida em que, de sua aplicação, forem obtidos os primeiros resultados. Isto constitui sua ambigüidade e sua intrínseca circularidade." Ao se aplicar esse movimento, constata-se 
que a "sua explicitação somente terá lugar no momento em que tiver sido atingida a situação hermenêutica necessária. Atingida esta, descobre-se que o método se determina a partir da coisa mesma" (STRECK, 2004, p. 4).

No movimento do círculo hermenêutico, a pré-compreensão antecede a compreensão/interpretação/aplicação que dará sentido aos resultados da pesquisa, onde o investigador (o aluno) estará diretamente implicado. Portanto, isto somente será possível a partir da experiência do pesquisador, mediante sua pré-compreensão de mundo, da vida e dos resultados que a pesquisa poderá produzir na sociedade. ${ }^{1} \mathrm{Na}$ necessidade de se aproximar o pesquisador do objeto pesquisado, portanto, é que Wilson Engelmann considera que sujeito, o pesquisador, está diretamente implicado, pois relacionado ao objeto de estudo, o qual interage com ele e sofre as consequências dos seus resultados, descobertas e potencialidades. Logo, não se trata de uma investigação alheia ao pesquisador, ele está no mundo onde a pesquisa será desenvolvida. Aí o significado do fenômeno. (ENGELMANN, 2007; ENGELMANN, 2016). Destarte, na figura do círculo hermenêutico, buscase a compreensão dos dados de pesquisa reunidos, constituindo-se em uma análise e interpretação deles buscando uma nova compreensão do fenômeno, que se concretiza, igualmente, em uma nova proposta, repetindo-se o círculo. ${ }^{2}$

O termo fenomenologia se refere exclusivamente ao modo como se demonstra e se trata o que nesta ciência deve ser tratado. A ciência dos fenômenos refere-se ao aprendizado dos objetos de tal maneira que se deve tratar de tudo que se está em discussão. Ensina Heidegger que a fenomenologia é a via de acesso e o modo de comprovação para se determinar o que deve constituir tema da ontologia, esta que só é possível como fenomenologia. O conceito fenomenológico de fenômeno compreende o ser dos entes, o seu sentido, suas modificações e derivados. O fenômeno é o que constitui o ser. (HEIDEGGER, 2008).

2 A perspectiva adotada por Fachin (2015, p. 116), tomando em conta as lições de ClausWilhelm Canaris, se alinha com o "método fenomenológico-hermenêutico" que sustenta este artigo, quando diz: "[...] Canaris concebe a hermenêutica como hábil a estabelecer critérios de objetivação dos valores que atuam com papel decisivo dentro do ordenamento jurídico. Não deve, [...], ser reduzida à concepção de doutrina, e nem mesmo de método. É, aqui, fundamentação. O fundamento, assim, não restringe a hermenêutica a método de interpretação do Direito Civil. Diversamente, como sustentação do próprio modo de ser do Direito Civil, se destina a construí-lo teórica e pragmaticamente nos caminhos para a solução correta dos casos". 


\section{Da desconstrução à reconstrução do Direito Privado no paradigma constitucional: a pessoa como categoria jurídica no cenário tecnicista da chamada repersonalização do Direito}

O século XIX presenciou as mais profundas alterações no modo de se entender e de se realizar o Direito, especialmente no âmbito do denominado Direito Privado, dado o apogeu das grandes codificações. No século XX, por seu turno, é que a Ciência do Direito representou um espaço de "letargia relativa, desafiando as insuficiências do formalismo e provocando o discurso jurídico a ampliar as suas bases de incidência" (CANARIS, 2008, p. IX). Vislumbra-se, neste caminhar, um complexo cenário de realização da Ciência Jurídica em decorrência de diversos fatores, tais como a crise na distinção entre o Direito Público e o Direito Privado - e, na verdade, a tomada de consciência da sua compenetração - a modificação nas condições sociais, dos costumes, dos estilos de vida, da própria legislação e dos valores fundamentais do ordenamento jurídico, e ainda a complexidade e pluralidade das fontes jurídicas, abrindo-se um espaço para o desenvolvimento doutrinário sobre o diálogo entre as fontes do Direito (ENGELMANN, 2012). Dessa forma, as inquietudes e interrogações devem se comunicar com o Direito, para que nele não existam conceitos e categorias indiscutíveis.

Indubitavelmente, uma das inquietudes que dominou a teoria do Direito é a ruptura da dicotomia entre o Direito Público e o Direito Privado, em que Teubner (2005) aduz que a desconstrução da dicotomia público/ privado já se tornou quase um ritual, mas ninguém sabe exatamente por qual outra classificação se poderia substituí-la. Para o sociólogo, os cientistas sociais analisaram repetidamente a separação entre Estado e sociedade, mas, em seu lugar, veem apenas uma politização de toda a sociedade. A ideologia da privatização aproveita essa des(cons) trução sem proposta de substituição, tendo êxito em apresentar a velha dicotomia como a única possibilidade institucional atualmente disponível e celebrando-se como um movimento para o aumento da eficiência: das hierarquias burocráticas aos mercados dinâmicos (TEUBNER, 2005, p. 236). 
Ocorre que, para o autor em análise, apesar de todas as críticas, a distinção público/privado demonstrou notável vitalidade através dos séculos, já que, em sua longa evolução, adaptou-se às profundas mudanças estruturais da sociedade. Francisco Amaral explica a questão da quebra dicotômica entre o Direito Público e o Direito Privado, no sentido de que a distinção sempre foi ideológica. Para o autor, essa distinção foi um dos postulados básicos do Estado Liberal, assim como o da divisão dos poderes e também o do caráter abstrato e geral das normas jurídicas. A separação dos dois ramos correspondia à existente entre os sistemas da política e da economia, com outra característica, a da abstenção do Estado em intervir na coletividade. Contrapunha-se "desse modo, a sociedade civil, que era a natural, dirigida pelas suas próprias leis, emanadas da natureza ou da razão, ao Estado, que era o organismo mantenedor da ordem econômica e social" (AMARAL, 2014, p.118-9). Nesse contexto de quebras paradigmáticas, Paulo Nalin (1998) identifica, como um dos grandes problemas a ser superado pelo sistema judiciário brasileiro, a ruptura entre uma sociedade brasileira pós-industrial neste início de século XXI e um sistema civil codificado que, originalmente, se vinculava a uma família nucleada no casamento, ao direito proprietário absoluto do indivíduo e ao contrato, cuja descrição econômica não supera a da histórica circulação de riquezas (NALIN, 2008, p. 30).

Tal superação vem representada pelo fenômeno da constitucionalização do Direito Privado, não mais se limitando o legislador à disciplina das relações patrimoniais. Seguindo o texto constitucional, o qual impõe deveres extrapatrimoniais nas relações privadas, tendentes à realização da personalidade e da tutela da dignidade da pessoa humana, o legislador cada vez mais condiciona a proteção de situações tradicionalmente disciplinadas sob a ótica exclusivamente patrimonial ao cumprimento de deveres não patrimoniais. É na esteira desse agora Direito Civil-Constitucional que emerge a necessidade de uma revisão de institutos jurídicos e de categorias jurídicas, haja vista que o Direito não logra mais o êxito de ser analisado em separado das outras ciências. Os dilemas da contemporaneidade colocam em xeque conceitos tradicionais, exigindo do intérprete-aplicador jurídico uma nova postura, 
afastada da mera subsunção normativa e com um olhar sistemático, em conjunto com diversos campos do saber, ou seja, em uma perspectiva interdisciplinar.

$\mathrm{Na}$ perspectiva da codificação hodierna, a pessoa centraliza as cogitações jurídicas, já que o ser é valorizado, cenário em que o ter assume uma função apenas complementar, consequência de uma nova realidade que o civilista contemporâneo passa a enfrentar, a qual exige a sua atenção para a defesa do ser humano e dos seus interesses inalienáveis, corolário, inclusive, da Constituição Federal de 1988, que considera a pessoa o seu vetor axiológico, o que vem expressamente consagrado no princípio da dignidade da pessoa humana. Partindo de tais ideias, Lorenzetti (1998, p. 83) destaca que o Direito Privado atual vai modificando seu enfoque, no sentido de que em uma sociedade de massa, a atuação do indivíduo não é indiferente ao que respeita os demais indivíduos e aos bens públicos. A consciência dessa interrelação obriga a enfocar o problema do Direito Privado de outra maneira, com necessidade de superar a noção de sujeito isolado para se chegar a uma ideia de sujeito situado, estabelecendo-se um modo de relação com os demais indivíduos.

Segundo Pontes de Miranda (2000, p. 29), por longo tempo, a técnica legislativa satisfez-se com a simples alusão à pessoa ou à ofensa à pessoa para as regras jurídicas concernentes aos efeitos da entrada do suporte fático, em que há ser humano, no mundo jurídico. Por isso, no suporte fático de qualquer fato jurídico há, necessariamente, alguma pessoa como elemento do suporte. Além do que, no suporte fático do fato jurídico de que surge direito de personalidade, o elemento subjetivo é ser humano. A personalidade, para o jurista, resulta da entrada do ser humano no mundo jurídico. ${ }^{3}$ É inolvidável, porém, que

3 Sobre o suporte fático da regra jurídica (Tatbestand), importante lembrar que Pontes de Miranda (1954, p. 19-20) o define como "aquele fato, ou grupo de fatos sobre o qual a regra jurídica incide, podendo ser da mais variada natureza, como, por exemplo, o nascimento do homem, o fato físico do mundo inorgânico, a doença, o ferimento, entre tantos outros. É incalculável o número de fatos do mundo, que a regra jurídica pode fazer entrar no mundo jurídico, que o mesmo é dizer-se pode tornar fatos jurídicos. [...] Fato jurídico é o suporte fático que o direito reputou pertencer ao mundo jurídico. A entrada dele nesse mundo, e não a sua permanência eficaz é que o pode definir". 
a temática abordada perpassa, obrigatoriamente, por uma análise que busque questionar as certezas em que se assentaram a construção paradigmática do Direito Privado, e, em especial do Direito de Família, quando a experiência sociológica ensina que as relações humanas cada vez mais se tornam líquidas. Trata-se do chamado "derretimento do sólido", que adquiriu uma nova concepção na modernidade, eis que afeta as instituições existentes, as molduras que circunscrevem o domínio das ações e escolhas possíveis.

Neste sentido, o ser humano vivencia uma chamada ldade da Técnica, a que Galimberti (2006) faz alusão e que se constitui em uma dessas representações figurativas de Bauman no sentido dos poderes de derretimento da modernidade, porque é uma era cujo tempo torna-se cada vez mais fluído, evasivo, desintegrado socialmente. Assim, se o poder da técnica não for corretamente compreendido, ele não significará o rompimento de barreiras, mas, em sentido contrário, será a representação do desengajamento e da fuga. Com o termo técnica entende-se tanto o universo dos meios, as tecnologias, quanto a racionalidade que preside o seu emprego, em termos de funcionalidade e existência. A técnica nasceu não como uma expressão do espírito humano, mas como um remédio à sua insuficiência biológica (GALIMBERTI, 2006, p. 9). Assim, ela é a essência do indivíduo, visto que ele não consegue sobreviver sem aquela. Isso implica, inclusive, uma mudança de pensamento, no sentido de superação da visão tradicional que via o ser humano como sujeito e a técnica como um instrumento à sua disposição.

Hoje, a técnica é o ambiente dele, o local que o rodeia e o constitui. Hottois (1999, p. 53) ensina que "se o homem tem de moderar sua atividade tecnocientífica, é essencial que ele não seja afetado por essa própria medida." A tecnociência adquiriu e aumentou o seu poder para modificar e manipular a natureza e a natureza humana, oferecendo possibilidades futuras e uma visão de futuro, segundo as quais o indivíduo e o mundo natural são radicalmente transformáveis.

Como aduz o autor, em lugar de um simples meio ou ferramenta - já que antes de tudo a técnica moderna não é uma ferramenta, e não tem nada que ver com ferramentas - a técnica é já o meio, o 
microcosmo planetário em constante evolução, em que passamos do nível mais concreto (o conforto doméstico, por exemplo) ao mais abstrato (as últimas informações sobre a expansão e origem do universo, por exemplo; informações conseguidas e difundidas graças à técnica) (HOTTOIS, 1999, p. 54). A tecnociência transforma, portanto, o mundo e a chamada ordem natural. Essa transformação pareceu relativamente benéfica enquanto não colocou-se em jogo frente ao próprio ser humano. Todavia, agora, a tecnociência igualmente se centra na sua condição ou na sua essência. Hoje, aproxima-se a passos largos o dia em que o corpo humano não poderá ser considerado como imutável. $\mathrm{O}$ indivíduo será capaz de remodelar não apenas cada corpo, um a um, mas também a raça humana em seu conjunto.

De acordo com Muraro (2009, p. 50), o fato de as descobertas científico-tecnológicas liberarem na espécie humana novas formas de ser é de tão grande importância que constitui uma das maiores preocupações do pensamento contemporâneo, de modo que toda tecnologia nova tende a criar um novo ambiente humano. É que a técnica, ensina Galimberti (2006, p. 381), foi promovida pela exigência humana de se dominar a natureza. O domínio, segundo ele, é a intenção básica e, ao mesmo tempo, o horizonte a partir do qual se dá a compreensão do mundo e o sentido dele. Como vontade de domínio, a técnica só pode alcançar o seu objetivo se for capaz de exercer um controle sobre o que acontece, no sentido de fazer acontecer e de fazer ser aquilo que está de acordo com o que foi projetado.

Pierre Lévy (2011, p. 11) leciona que há um movimento geral de virtualização que afeta não apenas a informação e a comunicação, mas também os corpos, o funcionamento econômico, os quadros coletivos de sensibilidade ou o exercício da inteligência. A virtualização atinge mesmo as modalidades do estar junto, a constituição do nós. No uso corrente, a palavra virtual é empregada com frequência para significar a pura e simples ausência de existência, a realidade. $O$ real seria a ordem do ter, enquanto que o virtual, a ordem do terás, da ilusão. O virtual não se opõe ao real, mas ao atual. 
Segundo Lévy (2011), o virtual é como o complexo problemático, o nós de tendências ou de forças que acompanha uma situação, um acontecimento, um objeto ou uma entidade qualquer, e que chama um processo de resolução: a atualização (LEVY, 2011, p. 16). Tratase de compreender a virtualização como o movimento inverso ao da atualização, consistindo em uma passagem do atual ao virtual, como uma mutação de identidade, um deslocamento do centro de gravidade ontológico do objeto considerado. Virtualizar uma entidade qualquer consiste em descobrir uma questão geral a qual ela se relaciona, em fazer mutar a entidade em direção à interrogação e em redefinir a atualidade de partida como uma resposta a uma questão particular.

Caberá ao homem, portanto, a missão de compensar a fenda que se formou e isso significa que, com o auxílio da razão prática, deverá dar uma resposta a um estado de coisas que ele próprio, com fundamento na razão técnica, criou. Trata-se, como o próprio Karl-Otto Appel (1988, p. 19) refere, de uma representação da problemática "actual da coeva situação de crise da humanidade no que diz respeito à situação ética do homem em geral." Observa-se, dessa forma, a necessidade de rompimento com aquele paradigma estanque, superando-se a chamada dicotomia entre o público e o privado. Ao se recepcionar na Constituição temas que antes compreendiam apenas ao estatuto privado, provocamse transformações no sistema do Direito Civil clássico, ou seja, a adaptação a uma nova realidade econômico-social, que obrigou o intérprete do Direito a repensar os valores ideologicamente consagrados no ordenamento jurídico e as influências interdisciplinares sofridas por ele nessa mutação.

Por tais razões, Fachin (2003, p. 252) elucida que o problema está vinculado às fronteiras das Ciências e aos eventuais limites éticos, morais ou jurídicos de um desenfreado progresso científico, pois alavancam uma outra visão de mundo, emancipatória e contra o dogmatismo. Mais do que isso, o autor destaca que se deve perguntar "a que" e "a quem" serve a biotecnologia, conquanto seja necessário um olhar crítico sobre o tempo, para que no corpo do Direito não ingresse tão simplesmente um novo estatuto do corpo humano a título de artefatos de mercantilização. 
O importante aspecto levantado por Fachin é objeto de profundos questionamentos efetuados por Patricia Palermini (2002, p. 11-2), quando sintetiza indagações no sentido de que, nestes tempos, como pode a ética enfrentar os poderosos interesses econômicos que estão em jogo no setor industrial da saúde e que conduza à realização, a qualquer preço, de certas aplicações da investigação biomédica? Além disso, deve-se lembrar a boa notícia: o mundo dos negócios agora tem sua própria ética, a ética nos negócios. Por que, então, apresentar o setor de saúde para as injunções de outros organismos éticos, especialmente aqueles de comitês de ética em que foram estabelecidas para definir padrões éticos nesta área? O que seria, de qualquer maneira, temer padrões éticos de saúde industrial? É fácil perceber que, num contexto marcado pela crescente desregulamentação do campo econômico, os fabricantes têm tudo a ganhar com uma regulação ética do seu setor. Dificilmente pode representar algo diferente de um convite amável para eles, para um pouco mais de altruísmo.

Como o fenômeno social e o ordenamento jurídico são os "dois lados de uma mesma moeda", pois há uma interdependência entre eles, exige-se o estudo de cada um dos seus institutos, tanto na perspectiva privada quanto nos aspectos publicistas, resolvendo-se a dicotomia. Mas, como pontua Perlingieri (2008, p. 143-144), se em uma sociedade com uma nítida distinção entre liberdade do privado e autoridade do público é possível distinguir a esfera do interesse dos particulares daquela do interesse público. Em uma sociedade como a atual, torna-se árdua, se não impossível, individuar um interesse privado que seja completamente autônomo, independente e isolado do interesse chamado público.

Resta individuar uma nova sistematização do Direito, para que haja a superação da mentalidade segundo a qual o Direito Privado é a liberdade dos particulares de cuidar dos próprios interesses, enquanto que o Direito Público oferece as estruturas e serviços sociais, a fim de permitir ao interesse privado a sua livre e efetiva realização (PERLINGIERI, 2008, p. 150). A superação dessa mentalidade conduziu à chamada despatrimonialização dos bens jurídicos ou do 
Direito Civil ${ }^{4}$, que vê confluir a proteção a direitos como a integridade física, nome, imagem, entre outros imanentes à esfera existencial da pessoa, em direta derivação constitucional. Insiste-se, portanto, sobre a relevância da tutela dos interesses da personalidade no Direito Privado, reconstruindo-se o Direito Civil, não com uma redução ou um aumento de tutela de situações patrimoniais, mas com uma proteção qualitativamente diversa. Para promover essas inovações no Direito Privado, que nada mais são do que mudanças na estruturação do Direito como um todo, será necessário revisitar e ressignificar a composição do suporte fático, tal qual planejado por Pontes de Miranda. O que não é uma tarefa fácil, considerando que o paradigma positivista ainda está muito presente, mostrando sinais de resistência e manutenção, apesar da evidente superação (ENGELMANN, 2011, p. 339-68).

\section{A família enquanto representação tradicional de um Direito de olhos fechados: de como a (r)evolução tecnocientífica abala as estruturas e faz desmoronar as certezas rumo a um repensar dos fundamentos de ser família}

É com Fachin (2009, p. 20) que sempre se relembra a ideia de que o movimento de publicização do Direito Privado emanava desde o Pós-II Guerra Mundial, mas a Constituição Federal "salientava-o de maneira dramática, afetando, frontalmente, os pilares das Codificações Oitocentistas Privadas, fazendo com que o Código Civil perdesse a centralidade de outrora para o texto constitucional". Trata-se da aceitação da ideia de que o Direito Civil não pode ser analisado apenas através dele próprio, senão com o influxo do Direito Constitucional, já que o Código não se torna mais a espinha dorsal do Direito Privado, conquanto o advento da Constituição e o surgimento de microssistemas tenham modificado tal concepção.

Com este termo, individualiza-se uma tendência normativo-cultural: evidencia-se que, no ordenamento, fez-se uma opção, que lentamente vai se concretizando entre personalismo (superação do individualismo) e patrimonialismo (superação da patrimonialidade fim a si mesma, do produtivismo, antes, e do consumismo, depois, como valores) (PERLINGIERI, 2008, p. 121). 
Como já referido anteriormente, as fronteiras entre o público e o privado cada vez mais se tornam menos claras, e, assim, a Constituição passa a se incorporar na seara privada, demonstrando, dentro da práxis jurídica, a sua força em institutos tipicamente de Direito Privado. $O$ contrato, a propriedade, a família, a função social, a boa-fé, tudo passa, agora, pelo crivo constitucional, balizando a releitura dos institutos privados à luz da Carta. Segundo Fachin (2009, p. 23), dos institutos jurídicos de Direito Privado, sobretudo civis, alguns deles, notadamente, foram alterados de maneira intensa. O Direito de Família e o Direito dos Contratos foram profundamente rejuvenescidos pela Constituição de 1988. Para o autor, a Constituição passou a ter uma função promocional nos contratos, com o Poder Público interferindo nas relações contratuais, definindo limites e constitucionalizando este ramo, que, até então, não sofria ingerência do Direito Público. Da mesma forma, o Direito de Família constitucionalizou-se, impondo uma radical reformulação dos critérios interpretativos adotados em matéria de família. A questão da propriedade, igualmente passa por transformações, haja vista que a função social da propriedade torna-se figura essencial para a compreensão deste instituto.

Logo, o Direito Contemporâneo necessita superar a crise que pode ser atribuída à fragilidade dos pilares da modernidade, porque pautava o sujeito enquanto individualidade e autonomia, para possibilitar o respeito à diferença e aos direitos fundamentais: é "tempo, pois, de operar criticamente e "reinventar" o Direito Civil." (FACHIN, 2003, p. 86). $E$ é assim que se inicia uma concepção de sociedade em função do homem, e não o contrário. O homem se realiza nas comunidades em que atua. A ruptura ocasionada pela transformação paradigmática no Direito Privado evidencia que o problema atual do Código Civil é a sua perda de capacidade de se apresentar como norma superior, papel que passa a ser destinado às Constituições e Tratados, princípios e valores. Como aduz Lorenzetti (2003, p. 230), o Direito pode ser um instrumento de justiça, de equilíbrio contratual e de inclusão na sociedade atual, instrumento de proteção de determinados grupos na sociedade, de garantia da dignidade da pessoa humana, de combate ao abuso de 
poder econômico e combate a toda atuação que seja contrária à boa-fé no tráfego social e no mercado.

O Direito Privado projeta-se para o âmbito das relações firmadas entre particulares sobre um ordenamento que organiza e estrutura esses pilares. Vale tecer alguns comentários sobre a função do contrato dentro da esfera clássica do Direito Privado. O instituto do contrato pressupõe vontade, ou melhor, a existência de um alguém que manifesta a sua vontade. Aqui, se está diante da condição de sujeito da pessoa que se coloca diante de outro sujeito para originar uma relação jurídica. Neste sentido, origina-se a noção de objeto que se coloca como um dos pilares que compõem o Direito Privado.

Neste contexto, percebe-se que o Brasil se manteve arraigado à tradição de dois séculos pretéritos, enquanto outros países já se deixavam influenciar por novas idéias, traduzidas especialmente por ocasião da Revolução Francesa, ou seja, liberdade, igualdade e fraternidade. Assim, mesmo diante da necessidade de uma renovação legislativa pelo ordenamento pátrio, o que houve foram apenas algumas tentativas fracassadas de elaboração de um diploma civil que consagrasse a aplicação equitativa da justiça. Por tal fato, asseverase que a não elaboração de um código no século XIX influenciou a preservação da tradição jurídica portuguesa, influenciando diretamente o Direito de Família e das Sucessões, por conservar, por exemplo, a indissolubilidade do matrimônio.

Assim, o Código Civil de 1916 impregnava-se de determinados preceitos morais, em vista da manutenção patriarcal da família, onde ao marido cabia exercer o papel de chefe da sociedade conjugal, cuja tarefa era administrar os bens particulares da mulher, fixando o domicílio da família, bem como autorizar a profissão da esposa - ou seja, nada mais do que a elevação do papel do homem na direção da sociedade conjugal. Neste ordenamento, portanto, o laço que unia o homem e a mulher, apenas, era indissolúvel, extinguindo-se com a morte de um dos cônjuges, e o casamento pautava-se pela comunhão universal de bens. Claro, eis que cabia ao homem o papel de chefiar os bens de toda a família. Ora, a classe aristocrata que dominava a sociedade à 
época jamais permitiria que a família não fosse constituída senão por objetivos econômicos, a fim de manter os seus interesses. Assim, nenhum espanto causa o Código Civil de 1916 em manter inalterados ditas aspirações, consagrando o casamento como a forma legítima de união entre as pessoas, de sexo oposto, ressalte-se.

Pode-se dizer, portanto, que o Código de 1916 firmava um tom patrimonialista, onde a realização humana dava-se através da propriedade. Não havia igualdade entre os cônjuges e entre os membros como um todo, afinal, os atuais princípios que vedam, por exemplo, a discriminação entre filhos legítimos e ilegítimos não estavam presentes no contexto social estruturado nesta época. Dentro destas reflexões, sempre oportuno lembrar-se da avaliação projetada por Beck e BeckGersheim (2011, p. 138):

$\mathrm{Na}$ vida cotidiana, como nas ciências sociais e políticas, duas suposições sobre casais e famílias predominam no Ocidente. Em primeiro lugar, a família e a globalização são mutuamente exclusivas; segundo, redes de relações são anacronismos, demasiado pesados e imóveis em face de um capitalismo global que apela para o ser humano flexível - que, em última análise, é o ser humano que está em seus próprios dois pés.

O cenário assim caracterizado, revela o horizonte de sentido hermenêutico onde se projetam as novidades observadas na estruturação atual das relações familiares, contrastando com o antigo diploma civil, ao trazer nos artigos 233 a 239 os direitos e deveres do marido, enquanto que estabeleceu nada mais do que quinze artigos, do 240 ao 255, os direitos e deveres da mulher. Nesse modelo, o patriarca era o chefe supremo da família matrimonializada e legítima. O marido era chefe da família e a mulher e os filhos eram hierarquicamente inferiores. Aliás, em todos os sentidos, o Direito de Família clássico assentou-se na desigualdade e nas presunções, a saber, a própria presunção pater is est quem nuptia demonstrant (LOBO, 2016), pela qual se impedia a discussão da origem da filiação se o marido não a negasse em curto prazo, haja vista os preconceitos da hegemonia familiar patriarcal e matrimonializada, já explicitada nas linhas acima. 
A família codificada de 1916 estava totalmente centrada em valores heteropatriarcais, diminuindo o papel da condição feminina na direção familiar. Afirma Ana Carla Harmatiuk Matos (2004, p. 8) que os papéis exercidos pelos membros da família já eram preestabelecidos, com funções já estipuladas para cada membro da família, onde "o homem e a mulher tinham suas atividades distintamente distribuídas em virtude do gênero". Neste modelo codificado, percebia-se uma hierarquia entre as funções, a fim de distribuir-se aos homens o poder e às mulheres os deveres conjugais, isso porque o patriarcalismo vigente tutelava a união para os fins de produção, eis que compreendia a noção de família constituída em torno de um núcleo econômico. Assim, ao patriarca eram destinados poderes superiores, traduzindo-se nesse papel que o poder tinha também nas relações fora da família, identificado com características predominantemente masculinas. Por tal fato, à mulher e aos filhos foram reservados os títulos de inferioridade em relação ao pai. Como revela Fachin (2013, p. 11), a Constitucionalização do Direito, especificamente na intensidade em que ocorreu na segunda metade do século $X X$, enfatiza essa lacuna de travessias que clama por respostas urgentes, quer através do sistema legal ou por meio de políticas públicas.

No sistema legal, uma destas formas foi pavimentada pela presença normativa dos princípios constitucionais, especialmente o da dignidade humana. Suas funções foram exponencialmente reforçadas pela crescente complexidade das relações humanas. A plataforma de governo é chamada, através do sistema legal, para, de forma rápida e eficiente, oferecer regras e soluções. Desejos e demandas que surgiram a partir de liberdade e autonomia buscam uma meta contraditória: a segurança e realização. Os paradoxos assumem os sistemas e criam um espaço de reflexão sobre os temperamentos que a esfera das relações sociais e privadas sugere.

Os três pilares fundamentais do Direito acabam por assumirem um novo contorno, passam a assumir novos papeis. Aquilo que antes denominava-se de contrato, família e propriedade, passa a ser visto como trânsito jurídico, projeto parental e titularidades. A família gradativamente surge como um fenômeno social, nesta tendência de remodelamento 
das relações sociais. O pluralismo das entidades familiares, uma das mais importantes inovações da Constituição brasileira, relativamente ao direito de família, encontra-se ainda cercada de perplexidades quanto a dois pontos centrais, que são questionados por Paulo Luiz Netto Lôbo (2016a): “a) há hierarquização axiológica entre elas?; b) constituem elas numerus clausus?”. O autor se propõe a enfrentar preferencialmente a segunda questão, gizando-a ao plano da Constituição brasileira, ou seja, extraindo sentido das normas nela positivadas, utilizando critérios reconhecidos de interpretação constitucional. Várias áreas do conhecimento, que têm a família ou as relações familiares como objeto de estudo e investigação, identificam uma linha tendencial de expansão do que se considera entidade ou unidade familiar. Na perspectiva da sociologia, da psicologia, da psicanálise, da antropologia, dentre outros saberes, a família não se resumia à constituída pelo casamento, ainda antes da Constituição, porque não estavam delimitados pelo modelo legal, entendido como um entre outros.

Berquó (1998, p. 414-5) lembra que, do ponto de vista demográfico e estatístico, mudanças e permanências marcaram a estrutura familiar brasileira nas últimas décadas. O caráter nuclear da família, isto é, casal com ou sem filhos, continua predominante, mas o tamanho da família diminuiu, e cresceu o número de uniões conjugais sem vínculos legais. As maiores transformações vêm ocorrendo no interior do núcleo familiar, assinaladas pela alteração da posição relativa da mulher e pelos novos padrões de relacionamento entre os membros da família. Por tal fato, hoje não se fala apenas em família, mas sim em famílias, como um meio de abrir as porteiras do passado e buscar uma nova realidade para as novas famílias que paulatinamente vão surgindo no campo do Direito. Resta refletir, no entanto, uma real fundamentação jurídica que albergue as novas formações dando-lhes legitimidade, para que a análise do sentido de família afetiva não seja um exercício solipsista dos intérpretes-aplicadores do Direito. A perspectiva fenomenológicohermenêutica sinaliza para a "escuta da tradição", no sentido de valorar a caminhada que as pessoas fazem e fizeram nas relações sociais familiares, abrindo-se espaço na estruturação do círculo hermenêutico 
para a atribuição jurídica do sentido, buscando juridicizar as inovações socialmente concebidas.

Vive-se atualmente a era das incertezas, fruto da complexidade das relações sociais, ou seja, uma teia heterogênea em que se colocam os acontecimentos. Portanto, a complexidade se apresenta como este conjunto emaranhado, da ambiguidade e da incerteza, dentro de um sistema organizado. É uma mistura de ordem e desordem, por onde se abre o sistema, emergindo dele o sujeito complexo, caracterizado por essas ambiguidades e incertezas. Destarte, esta matriz de pensamento contrapõe-se ao modelo cartesiano, pois, supera o método reducionista, de conceitos herméticos. Neste sentido, há uma nova seara comportamental dos três pilares do Direito Civil, que passam a considerar o sujeito em família, que se insere em um sistema jurídico, que busca definir um sujeito para um conjunto de objetos, pelo que o Direito Privado assume um papel de classificação dos fatos que a ele interessam, albergando-os, no sistema como fatos jurídicos.

Em vista das mutações nas relações sociais, para além da pura exegese, em que outrora se assentava a dicotomia entre o público e o privado, ou seja, entre a Sociedade e o Direito, os quais legitimavam a discriminação nas próprias relações familiares, posto que o diferente não era considerado como um sujeito de direito, diz-se que o Direito é um fenômeno social, que deve conhecer a sociedade em que se integra. Deste modo, a família, no contexto contemporâneo, define-se a partir da passagem do sistema codificado para o sistema constitucional, já que a Constituição Federal de 1988 assume o papel de ser norma fundamental, englobando a família, antes à margem do Código Civil de 1916, e, portanto, despatrimonializa o estatuto jurídico da família, para considerar agora o estatuto jurídico pessoal.

Neste diapasão, reflete Luiz Edson Fachin (2003, p. 80-9), ao afirmar que: na Constituição Federal encontra-se um conjunto significativo de dispositivos que tratam da regulamentação jurídica da família. $O$ valor e o "valer" da Constituição, sem embargo estão além da norma positivada. Assim, se apreende esse fenômeno, a "constitucionalização" do Direito de Família, através do qual a Constituição Federal ocupa o 
lugar classicamente deferido ao Código Civil e, hoje, é a lei fundamental, ali está a base do Direito de Família, regras e princípios fundamentais. Supera-se o modelo de grande família, onde permanecia o caráter patriarcal e hierarquizado da família. Não é mais o indivíduo que existe para a família, mas a família que existe para a pessoa, em busca da felicidade. Assim, o Direito de Família brasileiro contemporâneo acaba por trazer mais reflexões do que conclusões.

Neste sentido, em que a família passa a assumir novos contornos na sociedade plural, Pietro Perlingieri (2007, p. 244) afirma que a família como formação social é garantida em função da realização das exigências humanas, como lugar onde se desenvolve a pessoa. Para o autor, "o sangue e os afetos são razões autônomas de justificação para o momento constitutivo da família, mas o perfil consensual e a affectio constante e espontânea exercem cada vez mais o papel de denominador comum de qualquer núcleo familiar" (PERLINGIERI, 2007, p. 246). Desta forma, a função serviente da família deve ser realizada de forma integrada na sociedade, merecendo tutela em nome do princípio da dignidade, da igualdade e da democracia. Portanto, deve ser possível separar o velho e o novo no Direito. O Direito já não é mais o mesmo, eis que, historicamente, as teorias positivistas do Direito recusaram-se a fundar suas epistemologias numa racionalidade que desse conta do agir propriamente dito. Como alternativa, estabeleceram um princípio fundado em uma razão teórica pura, enxergando o direito como um objeto analisado a partir de critérios emanados de uma lógica formal rígida. Ora, a pretensão das teorias positivistas era oferecer à comunidade jurídica um objeto e método seguros para a produção do conhecimento científico, que desconsiderava os fatos sociais, excluindoos da teoria do Direito.

O novo constitucionalismo trouxe a preocupação de que o Direito deve se ocupar com a construção de uma sociedade justa e solidária, cujo desafio é fazer com que o direito não fique indiferente às injustiças sociais. Por isso é que Streck (2010) afirma não haver dúvida de que o novo constitucionalismo é sinônimo de novo paradigma, em que o direito deixa 
de ser meramente regulador para assumir uma feição de transformação das relações sociais. Leciona Streck que, se não há segurança para apontar as características de uma teoria efetivamente pós-positivista, há, entretanto, condições para que se possa dizer o que não é e o que não serve para a contemporânea teoria do direito, mormente em países com sistemas e ordenamentos jurídicos complexos. (STRECK, 2010, p. 200). Mas ao lado dessa perspectiva não se pode olvidar o grande problema que dificulta a aplicação do Direito na modernidade e a efetividade dos direitos constitucionais garantidos pela Carta, qual seja, o deslocamento para o Poder Judiciário do pólo de tensão dos conflitos. Aumentam-se os poderes dos juízes e dos tribunais. Eles não são mais a boca da lei, entretanto, passa-se a admitir o uso da discricionariedade judicial. Ao se reforçar o poder discricionário ao juiz, via ativismo judicial, retorna-se em direção ao positivismo.

O novo constitucionalismo proporcionou o surgimento de ordenamentos jurídicos constitucionalizados, a partir de ditames compromissórios e dirigentes, atravessando vertical e horizontalmente as relações sociais. Como, então, construir um discurso jurídico que dê conta da complexidade social sem recair no solipsismo do intérpreteaplicador, é a pergunta que se impõe.

\section{Uma família hi-tech e a necessária (re)leitura da teoria do fato jurídico, de Pontes de Miranda, pelo prisma do Direito Privado constitucionalizado: as famílias design como um modelo de suporte fático (in)definido no Direito Brasileiro}

Um dos recentes modelos familiares que sem tem conhecimento é o denominado family by design, ou família por design, oriunda da rede mundial de computadores, a partir da página eletrônica http://www. familybydesign.com/, a qual apresenta como principal objetivo fomentar a chamada coperantalidade ou doador conhecido. Aqui se tem um exemplo do processo de complexificação construído pelas inovadoras 
relações interpessoais surgidas no panorama social local e global. Tratase de uma nova entidade familiar, a da coparentalidade, formada pelo filho e os co-pais, que identificados, formam a família apenas destinada ao filho internético, que não conhecerá uma estruturação familiar tradicional, mas apenas um pai e uma mãe, que conceberam um filho com a assistência genética um do outro, nada mais havendo entre eles, em termos de relação familiar. O site www.familybydesign.com fundado por Darren Speedale, tem como objetivo promover arranjos familiares com objetivos procriativos, aproximando pessoas para atender os seus objetivos parentais. Deve-se ressaltar que não se tratarão de doadores anônimos, para uma reprodução assistida, embora tais técnicas possam ser utilizadas. Os co-pais serão pessoas identificadas e eleitas por determinados perfis.

A gestação, é, então, programada virtualmente, mediante a decisão conjunta dos parceiros em terem um filho e envolve os pares na Internet, mesmo que desconhecidos, a partir de questionários respondidos, onde são elencados dados pessoais a partir de informações, que poderão ser de interesse comum. Importa indagar se este modelo coaduna-se com a leitura repersonalizada do ordenamento jurídico, a qual contempla especial valor às questões existenciais, notadamente, a dignidade da pessoa humana, erigida no artigo $1^{\circ}$, inciso III, da Constituição Federal de 1988 e os direitos da personalidade, demarcados nos artigos 11 e seguintes do Código Civil de 2002 e que influenciaram a reformulação do que se entende por projeto parental, no sentido de ser a família o núcleo de realização pessoal dos seus membros.

Um dos aspectos atrativos do family by design reside no fato de que, para o fim de escolha do casal, dá-se notável importância às definições acerca da guarda e educação do filho projetado, quando um e outro já evidenciam como gostariam de cuidar do filho, ou como dividir as tarefas inerentes ao exercício do poder familiar de cada um, e como poderão trabalhar uma cooperação deles pais, entre si, para proteger os 
interesses maiores do filho, dentre outros vários aspectos que a página eletrônica recomenda que os co-pais atentem. ${ }^{5}$

Com efeito, claro que se percebe que filhos cibernéticos concebidos por pais internéticos, embora algumas críticas bioéticas, constituem uma nova realidade que não pode ser desconsiderada pelo direito de família. Os fatos da vida conferem realidades diferentes, no sentido da comunidade familiar, em seus mais diversos segmentos, razão pela qual, repisa-se, a tese discutirá a existência de um novo modelo familiar biotecnológico, formatado em uma necessária retomada do conceito de contrato, a partir de seu viés existencial.

Neste contexto, em que bioética, técnica e Direito se entrelaçam, é que se entende que as famílias design ou co-parentais induzem a uma nova categorização de família que a dogmática jurídica não consegue cerrar os olhos quando se coloca diante deste fenômeno. Além disso, o "suporte fático" de família não abriga essa modalidade familiar. Não é demais destacar que, para a realização de uma abordagem que pretenda ser completa acerca do sentido que o Direito de Família possui na contemporaneidade, é preciso, inicialmente, estudar a questão da própria formação do Estado Democrático de Direito, o movimento de codificação do Direito Civil, o Direito de Família Clássico, para, posteriormente, demonstrar a evolução pela qual a família tem passando ao longo dos últimos tempos, em especial, após a Constituição Federal de 1988.

$5 \quad$ No site se podem ler diversos aspectos a serem considerados sobre a coparentalidade: "[...] A dinâmica da interação entre os co-parceiros, indubitavelmente muda quando a criança nasce. Quando a criança chega, sua vida mudará de maneira que você não pode antecipar. Portanto, sugerimos que você pense em termos de seus objetivos nos relacionamentos que você está criando. Isto significa fazer um planejamento - e obter profundamente os detalhes - mas, ao mesmo tempo, manter uma flexibilidade significativa e reconhecer o fato de que algumas das dinâmicas de seu relacionamento de coparentalidade vão mudar ao longo do tempo. Para iniciar o processo, aqui estão algumas questões de discussão para, em seguida, gravar em um documento escrito: Quem vai decidir sobre o nome da criança? Será que vai ser mutuamente acordado ou será um dos pais autorizado a tomar essa decisão?Qual nome ou nomes aparecerão na certidão de nascimento?Se você precisar de algum outro tipo de ação legal para proteger os direitos de cada um dos pais, como uma adoção ou filiação reconhecida judicialmente, estabeleça quando isso vai acontecer, quem vai pagar por isso e que todas as partes fornecerão tudo o que um tribunal requer. Onde a criança residirá? Se a criança tiver mais de uma residência, quanto tempo será que ele/ela gasta em cada uma delas? Isto deverá mudar ao longo do tempo? [...]". (FAMILY BY DESIGN, 2016). 
Pontes de Miranda, ao caracterizar o "mundo jurídico", apresenta três Planos - a existência, a validade e a eficácia - que conformam a teoria do fato jurídico. O degrau de ingresso de um fato da vida no "mundo jurídico", por meio da sua passagem pelo Plano da Existência, que pode ser subdividido em 3 estágios": a) "o momento abstrato, que se dá pela descrição da hipótese fática pela norma jurídica", ou seja, é o delineamento abstrato dos requisitos que o fato deverá preencher para tornar-se jurídico; b) "momento de concreção, que se configura pela incidência da hipótese normativa sobre fato ou complexo de fatos da vida", as características do fato a ser juridicizado deverão ser previamente tipificadas; c) "momento de nascimento do fato jurídico", representando o momento culminante da subordinação do fato ou conjunto de fatos aos delineamentos preliminarmente inseridos de modo abstrato no bojo da norma jurídica.

Estes três estágios do Plano da Existência exigem a conexão da regra jurídica, do suporte fático e da incidência: "desde que há regra jurídica, há, debuxado por ela, que o previu, suporte fático, sobre que ela incida." A partir deste encadeamento, isto é, "[...] com a incidência da regra jurídica, o suporte fático, colorido por ela (= juridicizado), entra no mundo jurídico" (PONTES DE MIRANDA, 1983, p. 74, t. I, § 22). Esta operação mecânica do ingresso de um fato no "mundo jurídico" exige, como condição, a previsão dos seus contornos pela regra jurídica. A regra jurídica em Pontes de Miranda abrange o ius scripton e o ius non scripton (consuetudo). No tocante ao direito escrito, ele refere: "[...] a lei não é todo o direito. Erram, pois, os que não consideram direito os decretos, regulamentos e as próprias resoluções, isto é, as regras jurídicas elaboradas para a execução das leis" (PONTES DE MIRANDA, 1970, t. I, p. 299-300). A concepção legalista de Pontes de Miranda fica destaca por estas passagens. Além disso, ao tratar do conceito de interpretação, pode-se ler: "[...] a interpretação das regras dispositivas e das regras jurídicas interpretativas participa da hermenêutica das

6 Considerações sobre a Teoria do Fato Jurídica elaboradas por BRAGA, Paula Sarno. Primeiras reflexões sobre uma Teoria do Fato Jurídico Processual - plano de existência. In: DIDIER JR., Fredie; EHRHARDT JR., Marcos. Revisitando a Teoria do Fato Jurídico: homenagem a Marcos Bernardes de Mello. São Paulo: Saraiva, 2010, p. 446. 
leis (interpretação das regras jurídicas, dita das leis)" (PONTES DE MIRANDA, 1983, t. III, p. 322, § 325). Portanto, este artigo pretende apresentar algumas bases para a ressignificação da teoria do fato jurídico, de Pontes de Miranda, especialmente a estruturação do suporte fático, que não consegue justificar a juridicização de fatos novos, como a family by design. Não se pretende fazer uma crítica à proposta pontesiana, pois ele estava adequada aos pressupostos histórico-sociais da época em que foi formulado. Em pleno Século XXI, no entanto, muitas coisas mudaram, fazendo com que os comportamentos humanos não caibam mais na proposta do suporte fático de Pontes de Miranda.

Desde os anos 1980, o termo "design" tem sido apropriado pela mass media e pela indústria da propaganda como o "caminho" para agregar "desejabilidade" aos produtos. Consciência de estilo tornou-se condição sine qua non não apenas para os jovens, mas para todo um grupo de consumidores, e mesmo a mais sofisticada diferenciação entre produtos tem sido rotulada como possibilidades estilísticas de escolha determinadas pelo sexo, pela idade ou pela classe. O uso da palavra "design" passou a ser muito explorado pelos meios de comunicação, principalmente na publicidade, demonstrando com isso a força que o design agrega como valor de imagem, mas pouco se fala de seu conteúdo. (LANDIM, 2010, p. 23 e seguintes).

Paula Landim (2010) destaca um aspecto importante, de que o design engloba uma extraordinária variedade de funções, técnicas, atitudes, ideias e valores. É um meio através do qual se experimenta e se compreende o mundo que nos rodeia, desde bens de consumo e embalagens até sistemas de transporte e equipamento de produção, e não pode ser totalmente compreendido fora dos contextos social, econômico, político, cultural e tecnológico que levaram à sua concepção e realização.

Mais do que isso, considera que os aspectos psicológicos do design são também extensamente mencionados com uma importância sem precedentes. Há um consenso generalizado de que os produtos devem estar para além das considerações de forma e função se pretendem tornar-se "objetos de desejo" em um mercado cada vez mais 
competitivo. Para se conseguir isso, os produtos precisam estabelecer ligações emocionais agradáveis com seus usuários por meio do prazer da manipulação e/ou da beleza de sua forma. A emotividade é considerada por muitos dos designers não só como uma forma poderosa e essencial de facilitar ligações melhores e mais significativas entre os produtos e seus usuários, mas também um meio eficaz de diferenciar suas soluções das de seus competidores. Em uma sociedade globalizada, adquirese não apenas o objeto, mas o discurso do objeto. (LANDIM, 2010, p. 23 e seguintes). E aí, o questionamento se torna fundamental: o filho concebido é fruto do comportamento afetivo da parentalidade ou é um objeto de desejo individual de quem o plasmou em rede eletrônica? Por certo, essa pergunta demanda do intérprete-aplicador um novo agir para a busca de uma resposta constitucionalmente adequada. Pretende-se construí-la, a partir da reestruturação do suporte fático da teoria do fato jurídico, de Pontes de Miranda (1954). Para o jurista, a regra jurídica é a norma com que o homem, ao querer subordinar os fatos, a certa ordem e previsibilidade, procurou distribuir os bens da vida (PONTES DE MIRANDA, 1954, t. I, p. 3). Isso significa que há o fato de incidir, sempre que ocorre o que a regra jurídica prevê ou regula. $O$ que é pela regra previsto e sobre o que ela incide denomina-se de suporte fático, tido, por Pontes de Miranda, como um dos conceitos da mais alta relevância para as investigações científicas.

Os elementos do suporte fático são os pressupostos do fato jurídico, de modo que o fato jurídico é o que entra, do suporte fático, no mundo jurídico, mediante a incidência da regra jurídica sobre o suporte, ou seja, dos fatos jurídicos provém a eficácia jurídica. (PONTES DE MIRANDA, 1954 , t. I, p. 4). Todo fato é uma mudança no mundo. Os fatos que se passam no mundo jurídico, passam-se no mundo. Justifica-se, pela teoria pontesiana, que os fatos no mundo ou interessam ao Direito ou não interessam. Interessam-se, entram no subconjunto do mundo a que se chama mundo jurídico e se tornam fatos jurídicos pela incidência das regras jurídicas, normas abstratas que encontram os fatos. A incidência das regras jurídicas se dá sobre todos os casos que elas podem atingir. 
Por isso, são de conteúdo determinado. (ENGELMANN, 2010, p. 289 e seguintes). Nas palavras de Pontes de Miranda (1954, t. I, p. 19):

O suporte fático (Tatbestand) da regra jurídica, fato é, aquele fato, ou grupo de fatos que o compõe, e sobre o qual a regra jurídica incide pode ser da mais variada natureza: a) o nascimento do homem, b) o fato físico do mundo inorgânico, c) a doença, d) o ferimento, e) a entrada em terrenos, f) a passagem por um caminho, g) a goteira do telhado, h) a palavra do orador, i) os movimentos do pastor diante do altar, j) a colheita de frutos, $\mathrm{k}$ ) a simples queda do fruto. É incalculável o número de fatos do mundo que a regra jurídica pode fazer entrarem no mundo jurídico - que o mesmo é dizer-se pode tornar fatos jurídicos.

Em síntese, o fato jurídico é o suporte fático que o Direito reputou pertencer ao mundo jurídico. A entrada dele nesse mundo e não a sua permanência eficaz é que o pode definir. A questão é que para que se dê a incidência da regra jurídica, é preciso que o suporte fático existe. Se esse suporte fático não for suficiente ou haverá outra regra que atenda a essa insuficiência, ou não, e aí a regra jurídica deixa de incidir. A pretensa família desenhada pela relação virtual é um fato social. Aesse fato, haverá um instrumento jurídico que o regule: o acordo de coparentalidade. Logo, torna-se um fato jurídico. Entretanto, não há regras jurídicas no Direito de Família Codificado que atenda a esse suporte fático, quer seja no reconhecimento como entidade familiar, quer nos efeitos desse contrato no Brasil. Portanto, para se compreender a aplicação desse suporte no sistema jurídico brasileiro e haver o reconhecimento da família design como um modelo de família biotecnológica, a categoria suporte fático deverá ser ressignificada.

A proposição é que o suporte constitucional venha a substituir a noção clássica de Pontes de Miranda, mormente se construído sobre a premissa da constitucionalização do Direito. Quer dizer: ao invés de se buscar a juridicização nos elementos inexistentes de um suporte fático forjado no seio do Direito Privado - o Direito de Família - se propõe a constitucionalização do Código Civil, trazendo para o cenário da 
juridicização os princípios constitucionais como o da igualdade e o da dignidade da pessoa humana. Portanto, os desenhos projetados a partir do Family by design serão protegidos juridicamente a partir da irradiação dos efeitos trazidos pelos dois mencionados princípios.

Para Tepedino (2003-2004, p. 167-168), desde os anos oitenta que se sustenta, no Direito brasileiro, a imprescindibilidade da aplicação direta das normas constitucionais nas relações jurídicas de Direito Privado. Entretanto, no início dos anos noventa, com a promulgação da Constituição brasileira de 1988, surgiu, contra tal corrente, uma forte resistência dos civilistas mais tradicionais, ao argumento de que a chamada constitucionalização do Direito Civil representaria, em realidade, uma diminuição do papel da dogmática própria do Direito Privado no âmbito da teoria geral. Neste contexto, diante do Código Civil de 2002, impõe-se uma reflexão acerca dos paradigmas axiológicos que devem nortear o intérprete na reconstrução dos institutos de Direito Privado.

Mesmo admitindo-se difusamente a força normativa da Constituição, a aplicação direta dos princípios constitucionais, cujo conteúdo normativo foi proclamado pelos civilistas há vinte anos, nas relações de Direito Privado encontrou na doutrina e jurisprudência críticas que podem ser agrupadas em quatro objeções centrais: (i) os princípios constitucionais, mesmo tomados como preceitos normativos, constituemse em normas de organização política e social e, portanto, valer-se deles para a regulamentação das relações jurídicas interindividuais traduziria verdadeiro salto sobre o legislador ordinário, ao qual é dado disciplinar o direito privado; (ii) a baixa concretude dos princípios constitucionais, suscitaria exagerada e por vezes perigosa subjetividade dos juízes; (iii) as normas constitucionais sujeitam-se a reformas, compromissos e contingências políticas, ao contrário das normas do direito privado, muito mais afeitas à estabilidade própria da sua dogmática, em grande parte herdada, quase de forma intacta, desde o direito romano; e (iv) o controle de merecimento de tutela imposto pela aplicação automática das normas constitucionais, para além do juízo de ilicitude dos atos em geral, representaria uma ingerência valorativa indevida nos espaços 
privados, reduzindo o campo das escolhas e liberdades individuais. (TEPEDINO, 2003-2004, p. 169).

Todas as quatro críticas, ressalta Gustavo Tepedino, embora respeitáveis, relacionam-se com uma realidade inteiramente obsoleta, pressupondo o cenário característico da codificação do Século XIX, quando se delineava, então, uma clara dicotomia entre o Direito Público e o Direito Privado, este destinado à sublimação da autonomia privada. O Código Civil de 2002, embora desenhado sob a égide do paradigma patrimonialista, imaginando ciosamente um mundo privado que devesse se resguardar de ingerências estatais, fazendo por isso mesmo concessões por meio de restrições pontuais em cláusulas gerais, desponta em contexto axiológico que altera radicalmente o sentido emprestado para autonomia privada e para a aquisição e utilização dos bens.

A dignidade da pessoa humana impôs uma transformação na dogmática do Direito Civil, tornando obsoleta a profunda ruptura existente entre o Direito Público e Direito Privado, bem como ociosa a partição entre direitos reais e direitos obrigacionais, ou entre Direito Comercial e Direito Civil. Trata-se da unificação do Direito Privado, que à luz do princípio da dignidade humana, que reestrutura a técnica das relações jurídicas existenciais, com a tutela aos direitos da personalidade e, mais amplamente, a própria tutela da pessoa nas comunidades intermediárias, nas entidades familiares, na empresa, nas relações de consumo e na atividade econômica privada, entre outras, que passam a evidenciar a transformação profunda na dogmática civilista.

As novas tecnologias rompem com os compartimentos do Direito Público e do Direito Privado, invocando regulação a um só tempo de natureza privada e de ordem pública. A dignidade da pessoa humana há de ser tutelada e promovida, em última análise, nos espaços públicos e privados, daí resultando a imprescindibilidade de um controle da atividade econômica segundo os valores constitucionais, processo hermenêutico que, em definitivo, há de ser intensificado - e jamais arrefecido - com a promulgação de leis infraconstitucionais. (TEPEDINO, 2003-2004, p. 174). 
O desafio do jurista de hoje consiste precisamente na harmonização das fontes normativas, a partir dos valores e princípios constitucionais. O Código Civil deve contribuir para tal esforço hermenêutico. Portanto, deve ser interpretado à luz da Constituição, seja em obediência às escolhas político-jurídicas do constituinte, seja em favor da proteção da dignidade da pessoa humana, princípio fundante do ordenamento jurídico brasileiro. Nunca é demais refletir que o Código Civil de 2002 foi concebido no final da década de 1960 e início da década de 1970, e, por essa razão, questões referentes ao Direito de Família estão, hodiernamente, defasadas, de modo que as regras jurídicas não atingem a finalidade de proporcionar agilidade nas demandas jurídicas que possuem como pano de fundo a vida das pessoas, verdadeiros fatos sociais, premissa da teoria de Pontes de Miranda.

Concebe-se que o sistema jurídico contém regras jurídicas e essas se formulam com os conceitos jurídicos, muitas vezes indeterminados e cláusulas gerais, que advém dos fatos e das relações humanas. Para saber o suporte fático é necessário estudar o que as relações apontam. Fazendo-se isso é que se exerce a "função esclarecedora, discriminativa, crítica, retocadora, da pesquisa jurídica" (PONTES DE MIRANDA, 1983, t. I, p. X-XI). Marcos Bernardes de Mello (2008, p. 44-8), ao explicar a teoria pontesiana aduz que o jurista clássico mostrou que suporte fático (Tatbestand) é conceito universal, e não peculiar a um ou algum ramo da Ciência Jurídica (Direito Penal, onde primeiro foi tratado), além de ter criado e desenvolvido o conceito de incidência, efeito da norma jurídica que tem duas consequências essenciais: i) juridicizar o suporte fático, transformando-o em fato jurídico, e ii), por isso, tornar obrigatória a sua aplicação (da norma).

Ademais, ressalta Mello que a teoria de Pontes distinguiu o mundo dos fatos do mundo jurídico, dividindo, este último, de forma lógica, em planos da existência, da validade e da eficácia, mostrando daí que existir, valer e ser eficaz são três situações distintas em que se pode encontrar os fatos jurídicos, revelando a relação fundamental entre a norma jurídica, que define o mundo jurídico, o fato jurídico, que o compõe, e a eficácia jurídica, que o integra. Justifica-se, dessa forma, que a inexpressiva eficácia de direitos fundamentais decorre do 
despreparo dos juristas para enfrentarem, corajosamente, as causas apresentadas ao Direito na modernidade.

O problema, e aqui, valendo-se da lição de Warat (1993, p. 101), é que, no trabalho jurídico, os diversos profissionais são influenciados por um senso comum teórico, um pano de fundo que condiciona todas as atividades cotidianas. Sem ele, não pode existir práticas jurídicas, isto é, não se tem como produzir decisões ou significados socialmente legitimáveis. Eis assim que esse senso comum teórico representa um sistema que organiza os dados da realidade, pretendendo a reprodução de valores e práticas predominantes, ou seja, é um discurso o qual oferece respostas que apenas aludem ao real e apresenta um conjunto de questões em que as respostas já estão determinadas. E aqui se verifica uma perspectiva completamente equivocada, notadamente a partir da perspectiva hermenêutica adotada neste artigo: não se poderá ter a resposta antes da pergunta. É na dialética da pergunta e da resposta que se abrem as possibilidades hermenêuticas para a apreensão da realidade social pelo Direito, por meio da iluminação trazida pelas normas (= regras + princípios) jurídico-constitucionais. Nesse diapasão, como ensina Streck (2010a) negar a possibilidade de que possa existir uma resposta alinhada à Constituição do Brasil pode vir a se constituir em uma profissão de fé no positivismo, e, portanto, na discricionariedade judicial. Corre-se o risco de conceder ao juiz uma excessiva discricionariedade, um excesso de liberdade na produção de sentidos, acreditando que o Direito é apenas um conjunto de normas, e não norma, fato e direito.

Desde Pontes de Miranda (1983, t. I, p. 171) já se observava uma pequena referência à ideia de afetividade como contemplador das relações familiares. Veja-se:

Do par conjugal à família, do clã à fratria, à tribo, à nação, às chamadas raças, aos continentes, às civilizações, há a mesma exaltação sentimental, fecunda, que amplifica o eu, aumenta, cerebralmente todos os valores, transforma o objeto amado em sinal de sinais, alusão simbólica a tudo que é belo. É assim que se explicam as paixões do grupo binário (homem, mulher). (Grifado). 
A obra pontesiana reflete uma situação de época, conduzida pelo Código Civil de 1916, mas, em muitos momentos, as ideias do autor são plenamente aplicadas e vividas no contexto jurídico contemporâneo, mormente porque o aporte de Pontes de Miranda não é outro senão o da universalidade, pois ele concebe o Direito como fenômeno social. Por tal razão, é que se concorda com Sánchez e Moreno (2000, p. 29), quando referem que a variedade das relações sociais é imensa e nem todas são relevantes para a ordenação do Direito, porém, todas elas em seu conjunto destacam a alteridade do ser humano, é dizer, a necessidade de conceber um mundo ordenado na base de uma dimensão social do homem: em família, em associação, em relacionamentos de cooperação, entre outros. A norma (aqui entendido como o conjunto das regras e princípios), portanto, não deve estar desligada desta realidade social, muito antes pelo contrário, deve recolhê-la em sua estrutura como passo necessário prévio á regulação, finalidade última de toda norma jurídica. Por isso, quanto mais ajustada e correta seja a visão da realidade social contemplada na norma, mais probabilidade há de que sua posterior aplicação resulte satisfatória para os cidadãos.

Ademais, Jean Carbonnier (2001, p. 255) lembra que a família continua a ser o local mais comum de sensações agradáveis que possuem predominantemente o homem, com ou sem razão, na perseverança de ser. Eis, portanto, um caminho a se trilhar com base consistente a oferecer ao tema a salvaguarda jurídica imprescindível, considerando que, hodiernamente, as relações familiares reconhecidas pelo Direito são aquelas que se pautam na incidência da ideia de afetividade. Belmiro Welter (2009, p. 140) coloca que fazer uma parada obrigatória diante do texto do Direito de família é uma pré-condição para deixá-lo que diga alguma coisa, porque, quanto mais próximo o intérprete estiver do existente, do evento, do momento, mais distante estará da verdade hermenêutico-ontológica. O texto deve dizer algo ao intérprete, o qual perguntará o que há de novo, vinculando-se a ele, porque, onde não houver vínculo, não haverá diálogo.

Há, na verdade, uma mudança na agenda existencial das pessoas, dentro desse mundo líquido em que se vive, para parafrasear Bauman 
(2004, p. 9). Aliás, é ele que refere que relacionamento é o assunto mais quente do momento, e, aparentemente, o único jogo que vale a pena, apesar de seus óbvios riscos.

De acordo com o sociólogo, hoje em dia as atenções humanas tendem a se concentrar nas satisfações que se espera obter nas relações, porque, de alguma forma, estas não têm sido consideradas plena e verdadeiramente satisfatórias. Diferentemente de relações, parentescos, parcerias e noções similares, as quais Bauman (2004) considera que, ao mesmo tempo em que ressaltam um engajamento mútuo, omitem a sua falta de compromisso, uma rede serve de matriz tanto para conectar quanto para desconectar. A palavra rede sugere momentos nos quais se está em contato, intercalados por períodos de movimentação a esmo. É nela em que as conexões são estabelecidas e cortadas por escolha.

É neste contexto das relações em rede e da possibilidade de rompimento de tais conexões, que Bauman (2004, p. 12) afirma que as relações virtuais parecem feitas sob medida para o líquido cenário da vida moderna, em que se espera e se deseja que as possibilidades românticas surjam e desapareçam numa velocidade crescente e em volume cada vez maior, "aniquilando-se mutuamente e tentando impor aos gritos a promessa de ser a mais satisfatória e a mais completa". Ao contrário de relacionamentos reais, o sociólogo entende que é fácil entrar e sair dos relacionamentos virtuais, pois, em comparação com a coisa autêntica, pesada, lenta e confusa, eles parecem limpos e fáceis de usar e manusear.

Novamente, se pode trazer Ulrick Becke Elisabeth Beck-Gernsheim (2011, p. 158), quando refletem os efeitos dos impactos biotecnológicos na própria constituição da afetividade dentro das relações e o próprio sentido de amor distante ou amor à distância, que passa a impregnar as relações entre as pessoas. Neste sentido: qual é o significado de termos como "pai", "mãe" e "família" no caso de uma criança que é concebida como encomenda no laboratório, usando "biomaterial" derivado de pessoas estrangeiras que vivem "em outro lugar", em uma terra distante? 
Quem tem que direitos e obrigações aqui? A quem a criança pertence? Que mãe se supõe produzir amor maternal? Onde é que o amor se torna seu oposto, transformando-se em um conflito de interesses? Ademais, os autores prosseguem:

A nossa resposta é que o amor e a família perdem o seu laço que o prendia a um único lugar e, passa a procurar a sua sorte na diversidade do mundo. Isto dá origem a um amor distante, que é de inicialização geográfica e cultural. Ou aqui ou ali, ou nós ou eles - todas essas alternativas desaparecem do horizonte do amor. Poucas linhas divisórias absolutamente insuperáveis permanecem: não a cor de sua pele, sua nacionalidade ou religião, ou até mesmo as distâncias que separam os países e continentes. Pelo contrário, é o outro geograficamente distante que contém os atraentes de novas possibilidades de amor. $\mathrm{O}$ amor brotou novas asas. (BECK; BECK-GERNSHEIM, 2011, p. 166167).

A transformação que se observa na constituição das famílias envolve a transformação da intimidade que é sugerida por Giddens (2012, p. 271), quando explica que, no século XVIII, verificou-se a expansão de um chamado amor romântico, o qual tendia à dominância dos homens sobre as mulheres, e que foi substituído, com a fragmentação deste por um amor confluente, ativo e contingente, contrariando as qualidades da eternidade e singularidade do amor romântico. Hoje, as pessoas cada vez mais buscam o ideal de um relacionamento puro, no qual os casais se mantêm porque assim decidem. $O$ amor se baseia na intimidade emocional que gera confiança. Destarte, o intérprete não atribui um sentido para o Direito de Família dissociado da história, mas compreende a partir das possibilidades dadas pela tradição, pelo tempo, não havendo um grau zero, novamente, para se utilizar da ideia de Streck e a questão da inexistência do grau zero na linguagem. É apenas pelos conceitos prévios que o intérprete poderá acessar as coisas como elas são, desvelando-se no e o mundo humano. 


\section{Conclusão}

O primeiro passo para a compreensão da metodologia proposta no artigo está na própria reformulação do conceito de regra jurídica em sentido mais amplo, passando da técnica legislativa do tipo hermético (preceito e sanção), às cláusulas gerais, abrangentes e abertas. Além disso, trabalhar a noção de norma jurídica como um gênero que abriga duas espécies: a regra e os princípios (ENGELMANN, 2001). Ocorre que, na verdade, entende-se que o modelo estratificado da regra jurídica não se coaduna com a necessária plasticidade das normas com tendências sociais, o que se desvela na própria Constituição Federal, a qual possui diferentes dispositivos ávidos por sua concretização a partir de uma experiência hermenêutica.

Ainda tem-se a redução do contexto técnico da linguagem empregada nos textos legais, visando o legislador, com isto, promover um atendimento às especificidades dos setores destinatários da regra elaborada, como a informática, a economia, entre outros, pois o comprometimento legislativo com uma linguagem que se distancie do apuro técnico e específico do Código Civil implica maior eficácia das regras constitucionais e infraconstitucionais, realizando-se o comando constitucional do Estado Democrático de Direito a partir da funcionalização da linguagem técnico-jurídica. A regra constitucional, enquanto vocacionada à programação das atividades do Estado e ao encaminhamento de um comportamento social desejado, está vinculada a uma função promocional do Direito, o que não se configurava no âmbito do Código Civil de 1916. Eis, assim, que a constitucionalização do Direito Civil reside na tendência de se condicionar a efetividade dos direitos patrimoniais dos atos jurídicos à realização de valores superiores do ordenamento, tal como a dignidade da pessoa humana, até porque esse valor jurídico, dentre outros, encontra-se no vértice da estrutura legal.

Revela-se a necessidade de um novo olhar para as fontes do Direito e a reafirmação da prevalência da Constituição em face do Código Civil. Tal premissa é corolário direto da anterior, quando 
reafirmada a interpretação da regra civil conforme a Constituição. $\mathrm{Na}$ sua leitura, tal visão não pretende diminuir ou aniquilar o relevante papel do Código Civil na sociedade, mas conservar e renovar os institutos civilísticos, dentro do parâmetro já consagrado pela Constituição Federal de 1988, cuja aplicação coaduna-se às relações interprivadas, na medida do reconhecimento de um ordenamento jurídico unitário e da normativa constitucional como regra de conduta, posta no sentido da funcionalização dos institutos jurídicos pré-existentes e abertos às novas tendências sociais.

$\mathrm{Na}$ perspectiva da codificação hodierna, a pessoa centraliza as cogitações jurídicas já que o ser é valorizado, cenário em que o ter assume uma função apenas complementar. Isso é consequência de uma nova realidade que o civilista contemporâneo passa a enfrentar, a qual exige a sua atenção para a defesa do ser humano e dos seus interesses inalienáveis, corolário, inclusive, da Constituição Federal de 1988, que considera a pessoa o seu vetor axiológico, o que vem expressamente consagrado no princípio da dignidade da pessoa humana. Por isso, é no suporte fático de qualquer fato jurídico que surge Direito e onde há necessariamente alguma pessoa como elemento do suporte. Além do que, no suporte fático do fato jurídico, exsurge o direito de personalidade, cujo elemento subjetivo é ser humano. A personalidade deve significar a entrada do ser humano no mundo jurídico.

É inolvidável, portanto, que a temática abordada perpassa, obrigatoriamente, por uma análise que busque questionar as certezas em que se assentaram a construção paradigmática do Direito Privado, e, em especial do Direito de Família, quando a experiência sociológica ensina que as relações humanas cada vez mais se tornam líquidas. É nesse chamado derretimento do sólido, que se adquire uma nova concepção de família na modernidade, eis que afeta as instituições existentes, as molduras que circunscrevem o domínio das ações e escolhas possíveis. Esse é o espaço para a estruturação do diálogo entre as fontes do Direito, que é o espaço para se operar a modernização dos elementos estruturantes da teoria do fato jurídico, desenhada por Pontes de Miranda. Uma providência que projeta possibilidades de ressignificação 
é a abertura da noção de regra jurídica, com a qual Pontes de Miranda trabalhou, para a noção de norma jurídica, onde, ao lado das regras, se projetam as possibilidades regulatórias dos princípios, especialmente o da igualdade e o da dignidade da pessoa humana.

Segundo Pontes de Miranda (1983, t. I, p. X-XI), "[...] o sistema jurídico contém regras jurídicas; e essas se formulam com os conceitos jurídicos. Tem-se de estudar o fático, isto é, as relações humanas e os fatos, a que elas se referem, para se saber qual o suporte fático, isto é, aquilo sobre que elas incidem, apontado por elas". Aqui se visualiza o detalhe do entendimento pontesiano: o suporte fático, que representa o elo de comunicação entre o "mundo jurídico" e o "mundo dos fatos", preverá em caráter preliminar o fato da vida e os seus contornos, que poderão receber os efeitos jurídicos. Reforça-se, aqui, a necessidade da regra jurídica "adivinhar" como os fatos da vida ocorrerão. Os contornos não "adivinhados" ficam fora de regulação.

Outra passagem de Pontes de Miranda (1983, t. I, p. XI) evidencia a incapacidade dessa forma de conceber o jurídico a partir dos contornos inusitados trazidos pelos novos formatos das famílias do século XXI: "[...] é fácil compreender-se qual a importância que tem a exatidão e a precisão dos conceitos, a boa escolha e a nitidez deles, bem como o rigor na concepção e formulação das regras jurídicas e no raciocinar-se com elas". Justamente, conforme destacado, a exatidão e a precisão são duas características perseguidas pelo positivismo jurídico de viés legalista, muito presenta na proposta pontesiana. Embora sejam importantes, essas propriedades dificilmente serão conseguidas no mundo em que a criatividade humana gera novas formas de relacionamento e constituição familiar. Aqui está o contexto estruturante principal, onde se pretende projetar o resultado do diálogo entre as fontes do Direito, viabilizando a constitucionalização do suporte fático, a fim de abrigar formatos familiares que não se encontram previamente caracterizados no suporte fático da família e do Direito de Família como um todo. 


\section{Referências}

AMARAL, Francisco do. Direito civil: introdução. 8.ed. Rio de Janeiro: Renovar, 2014.

APPEL, Karl-Otto. Ética e responsabilidade: o problema da passagem para a moral pós-convencional. Lisboa: Instituto Piaget, 1988.

BAUMAN, Zygmunt. Amor líquido: sobre a fragilidade dos laços humanos. Tradução Carlos Alberto Medeiros. Rio de Janeiro: Zahar, 2004.

BAUMAN, Zygmunt. Modernidade líquida. Tradução Plínio Dentzien. Rio de Janeiro: Zahar, 2001.

BECK, Ulrick; BECK-GERSHEIM, Elisabeth. Distant love: personal life in the global age. Translated by Rodney Livingstone. Cambridge: Polity Press, 2011.

BERQUÓ, Elza. Arranjos familiares no Brasil: uma visão demográfica. In: SCHWARCZ, Lilia Moritz. História da vida privada no Brasil: contrastes da intimidade contemporânea. São Paulo: Companhia das letras, 1998. v. 4

BRAGA, Paula Sarno. Primeiras reflexões sobre uma teoria do fato jurídico processual: plano de existência. In: DIDIER JR., Fredie; EHRHARDT JR., Marcos. Revisitando a teoria do fato jurídico: homenagem a Marcos Bernardes de Mello. São Paulo: Saraiva, 2010.

CANARIS, Claus-Wilhelm. Pensamento sistemático e conceito de sistema na ciência do direito. Tradução A. Menezes Cordeiro. 4.ed. Lisboa: Fundação Calouste Gulbenkian, 2008.

CARBONNIER, Jean. Flexible droit: pour une sociologie du droit sans rigueur. 10.ed. Paris: LGDJ, 2001.

DIDIER JR., Fredie; EHRHARDT JR., Marcos. Revisitando a teoria do fato jurídico: homenagem a Marcos Bernardes de Mello. São Paulo: Saraiva, 2010.

ENGELMANN, Wilson. Direitos bio-humanos-éticos: os humanos buscando 'direitos' para proteger-se dos avanços e riscos 
(desconhecidos) das nanotecnologias. In: Anais do XIX ENCONTRO NACIONAL DO CONPEDI. Disponível em: <http:// www.conpedi.org. $\mathrm{br} / \mathrm{manaus} /$ arquivos/anais/fortaleza/3400.pdf>. Acesso em: $10 \mathrm{fev}$. 2016.

ENGELMANN, Wilson. Direito natural, ética e hermenêutica. Porto Alegre: Livraria do Advogado, 2007.

ENGELMANN, Wilson. Crítica ao positivismo jurídico: princípios, regras e o conceito de direito. Porto Alegre: Sérgio Antonio Fabris Editor, 2001.

ENGELMANN, Wilson. O diálogo entre as fontes do Direito e a gestão do risco empresarial gerado pelas nanotecnologias: construindo as bases à juridicização do risco. In: STRECK, Lenio Luiz; ROCHA, Leonel Severo; ENGELMANN, Wilson (Org.). Constituição, sistemas sociais e hermenêutica: Anuário do Programa de Pós-Graduação em Direito da UNISINOS. Porto Alegre: Livraria do Advogado, 2012. v. 9. p. 319-344.

ENGELMANN, Wilson. Os avanços nanotecnológicos e a (necessária) revisão da Teoria do Fato Jurídico de Pontes de Miranda: compatibilizando "riscos" com o "direito à informação" por meio do alargamento da noção de "suporte fático". In: CALLEGARI, André Luís; STRECK, Lenio Luiz; ROCHA, Leonel Severo (Org.). Constituição, sistemas sociais e hermenêutica: anuário do programa de pósgraduação em direito da unisinos. Porto Alegre: Livraria do Advogado, 2011. v. 8. p. 339-368.

ENGELMANN, Wilson. A (re)leitura da teoria do fato jurídico à luz do "diálogo entre as fontes do Direito": abrindo espaços no Direito Privado constitucionalizado para o ingresso de novos direitos provenientes das nanotecnologias. In: CALLEGARI, André Luís; STRECK, Lenio Luiz; ROCHA, Leonel Severo (Org.). Constituição, sistemas sociais e hermenêutica: anuário do Programa de Pós-Graduação em Direito da UNISINOS. Porto Alegre: Livraria do Advogado Editora. 2010. v. 7. p. 289-308.

FACHIN, Luiz Edson. Direito de família: elementos críticos à luz do novo código civil brasileiro. 2. ed. Rio de Janeiro: Renovar, 2003. 
FACHIN, Luiz Edson. Mind the gap between the new portfolio and the so-called old systems. Civilistica.com. Rio de Janeiro, a. 2, n. 1. jan.mar./2013. p. 1-30.

FACHIN, Luiz Edson. O Direito Civil Contemporâneo, a norma constitucional e a defesa do pacto emancipador. In: CONRADO, Marcelo; PINHEIRO, Rosalice Fidalgo. (Coord.). Direito privado e constituição: ensaios para uma recomposição valorativa da pessoa e do patrimônio. Curitiba: Juruá, 2009. p. 17-32.

FACHIN, Luiz Edson. Teoria crítica do direito civil à luz do novo código civil brasileiro. 2. ed. Rio de Janeiro: Renovar, 2003.

FACHIN, Luiz Edson. Direito civil: sentidos, transformações e fim. Rio de Janeiro: Renovar, 2015.

FAMILY BY DESIGN. Co-parenting agreements: what you need to consider. Disponível em: <http://www.familybydesign.com/content/ learn/legal/co-parenting-agreements-what-you-need-to-consider/>. Acesso em: 08 fev. 2016.

GADAMER, Hans-Georg. Verdade e método. Tradução Enio Paulo Giachini. Petrópolis: Vozes, 2002. v. 2.

GALIMBERTI, Umberto. Psiche e techne: o homem na idade da técnica. Tradução José Maria de Almeida. São Paulo: Paulus, 2006.

GIDDENS, Anthony. Sociologia. 6. ed. Tradução Ronaldo Cataldo Costa. Porto Alegre: Penso, 2012.

HOTTOIS, Gilbert. EI paradigma bioético: una ética para la tecnociencia. Barcelona: Anthropos editorial, 1999.

INTERDISCIPLINARITY: Why scientists must work together to save the world. In: Nature, v. 525, 17 set. 2015. p. 305.

KONDER, Carlos Nelson. Distinções hermenêuticas da constitucionalização do direito civil: o intérprete na doutrina de Pietro Perlingieri. Revista da Faculdade de Direito UFPR, Curitiba, v. 60, n. 1, p. 193-213, jan./abr. 2015.

LANDIM, Paula da Cruz. Design, empresa, sociedade. São Paulo: UNESP, 2010. Disponível em: <http://static.scielo.org/scielobooks/ vtxgm/pdf/landim-9788579830938.pdf>. Acesso em: 08 fev. 2016. 
LÉVY, Pierre. O que é o virtual? Tradução Paulo Neves. 2.ed. São Paulo: Ed. 34, 2011.

LÔBO, Paulo Luiz Netto. Entidades familiares constitucionalizadas: para além do numerus clausus. Disponível em: <http://www.egov.ufsc. br/portal/sites/default/files/anexos/9408-9407-1-PB.pdf>. Acesso em: 03 fev. 2016a.

LÔBO, Paulo Luiz Netto. Princípio jurídico da afetividade na filiação. Disponível em: <http://www.ibdfam.com.br/public/artigos. aspx?codigo=109>. Acesso em: 03 fev. 2016.

LORENZETTI, Ricardo Luís. Fundamentos do direito privado. São Paulo: RT, 1998.

LORENZETTI, Ricardo Luís. A descodificação e a possibilidade de ressistematização do Direito Civil. In: FIUZA, César; SÁ, Maria de Fátima Freire de; NEVES, Bruno Torquato de Oliveira. Direito Civil: atualidades. Belo Horizonte: Del Rey, 2003.

MATOS, Ana Carla Harmatiuk. União entre pessoas do mesmo sexo: aspectos jurídicos e sociais. São Paulo: Del Rey, 2004.

MELLO, Marcos Bernardes de. A genialidade de Pontes de Miranda. Revista Getúlio Vargas, São Paulo, p. 44-48, mar. 2008.

MIRANDA, Francisco Cavalcante Pontes de. Tratado de direito privado: parte geral. Rio de Janeiro: Borsoi, 1954. t. I.

MIRANDA, Francisco Cavalcante Pontes de. Tratado de direito privado: parte geral. 4. ed. São Paulo: Revista dos Tribunais, 1983. t. I. MIRANDA, Francisco Cavalcante Pontes de. Tratado de direito privado. 4. ed. São Paulo: RT, 1983. t. III.

MIRANDA, Francisco Cavalcante Pontes de. Tratado de direito privado. Campinas: Bookseller, 2000. t. VII.

MIRANDA, Francisco Cavalcante Pontes de. Comentários à Constituição de 1967 com a Emenda n 1 de 1969. 2. ed. São Paulo: RT, 1970. t. I.

MURARO, Rose Marie. Os avanços tecnológicos e o futuro da humanidade: querendo ser Deus? Rio de Janeiro: Vozes, 2009. 
NALIN, Paulo. Do contrato: conceito pós-moderno em busca de sua formulação na perspectiva civil-constitucional. 2.ed. Curitiba: Juruá, 2008.

PALERMINI, Patricia. Misère de la bioéthique. Bruxelles: Édtions Labor, 2002.

PERLINGIERI, Pietro. Perfis do direito civil: introdução ao direito civil constitucional. Tradução Maria Cristina De Cicco. 3.ed. Rio de Janeiro: Renovar, 2007.

PERLINGIEEI, Pietro. O direito civil na legalidade constitucional. Rio de Janeiro: Renovar, 2008.

RAMOS, Carmem Lúcia Silveira. A constitucionalização do direito privado e a sociedade sem fronteiras. In: FACHIN, Luiz Edson (Coord.). Repensando fundamentos do Direito Civil brasileiro contemporâneo. Rio de Janeiro: Renovar, 1998. p. 3-29.

SANCHÉZ, Emílio M. Beltrán; MORENO, F. Javier Orduna. Curso de derecho privado. 4.ed. Valencia: Tirant Le Blanch Livros, 2000.

STEIN, Ernildo. Introdução ao Método Fenomenológico Heideggeriano. In: Sobre a Essência do Fundamento. Conferências e Escritos Filosóficos de Martin Heidegger. Tradução de Ernildo Stein. São Paulo: Abril Cultural, 1979. (Coleção Os Pensadores).

STRECK, Lenio Luiz. Aplicar a letra da lei é uma atitude positivista?. Revista NEJ, Itajaí, v. 15, n. 1. p. 158-173, jan./abr. 2010a. Disponível em: <http://www.univali.br/periodicos>. Acesso em: 03 fev. 2016.

STRECK, Lenio Luiz. Diálogos (neo)constitucionais. In: DUARTE, Écio Oto Ramos; POZZOLO, Susanna. Neoconstitucionalismo e positivismo jurídico: as faces da teoria do direito em tempos de interpretação moral da Constituição. 2.ed. São Paulo: Landy, 2010.

STRECK, Lenio Luiz. Jurisdição constitucional e hermenêutica: uma nova crítica do direito. 2. ed. Rio de Janeiro: Forense, 2004.

TEPEDINO, Gustavo. Normas constitucionais e Direito Civil. Revista da Faculdade de Direito de Campos, ano IV, n. 4, n. 5 - 2003-2004. p. 167-175. 
TEPEDINO, Gustavo. Premissas metodológicas para a constitucionalização do direito civil. In: Temas de Direito Civil. 4. ed. rev. e atual. Rio de Janeiro: Renovar, 2008. p. 01-22.

TEUBNER, Gunther. Direito, sistema e policontexturalidade. São Paulo: UNIMEP, 2005.

TOO CLOSE FOR COMFORT? Relationships between industry and researchers can be hard to define, but universities and other institutions must do more to scrutinize the work of their scientists for conflicts of interest. In: Nature, v. 525, p. 289, 17 set. 2015.

WARAT, Luis Alberto. Introdução geral ao direito III: o direito não estudado pela teoria jurídica moderna. Porto Alegre: Sérgio Antônio Fabris Editor, 1997.

WARAT, Luis Alberto. O senso comum teórico dos juristas. In: SOUSA JUNIOR, José Geraldo de. Introdução crítica ao direito. 4. ed.

Brasília: Universidade Federal de Brasília, 1993. p. 101-104.

WELTER, Belmiro Pedro. Teoria tridimensional do direito de família. Porto Alegre: Livraria do Advogado, 2009.

Recebido em: 28/02/2016

Aprovado em: 25/08/2016 